\title{
Phase shift in hippocampal circadian rhythm during the latent period of epileptic rats
}

\author{
David A Stanley ${ }^{1}$, Paul R Carney ${ }^{2,3,4,5}$, Mansi B Parekh², Thomas H Mareci ${ }^{4,5,6}$, Sachin S Talathi ${ }^{2,3,4^{*}}$, William L Ditto \\ From Twentieth Annual Computational Neuroscience Meeting: CNS*2011 \\ Stockholm, Sweden. 23-28 July 2011
}

Since the late $19^{\text {th }}$ century, clinicians have been aware that epileptic seizures are predisposed to occur at specific times of day. Recent experiments by our group in a chronic limbic epilepsy animal model have lead to the hypothesis that epilepsy following brain injury may emerge as a circadian disorder $[1,2]$. Specifically, we extracted two distinct classes of population spikes (PS) from CA1 local field potential data. Tracking the firing rate activity of these PS revealed: (a) The rate of PS oscillated with near 24-hour period in both sham controls and epileptic rats. (b) During the epileptogenesis latency period, immediately following electrically induced brain injury, a phase shift greater than $90^{\circ}$ materialized between the two classes of population spikes. In addition, we observed a gradually evolving imbalance in which the average firing rate of one PS type increased at the expense of the other over a period of weeks, up until the rat's first spontaneous seizure [1].

Our present goal is to explain the source of the PS phase shift in relation to the circadian perturbations
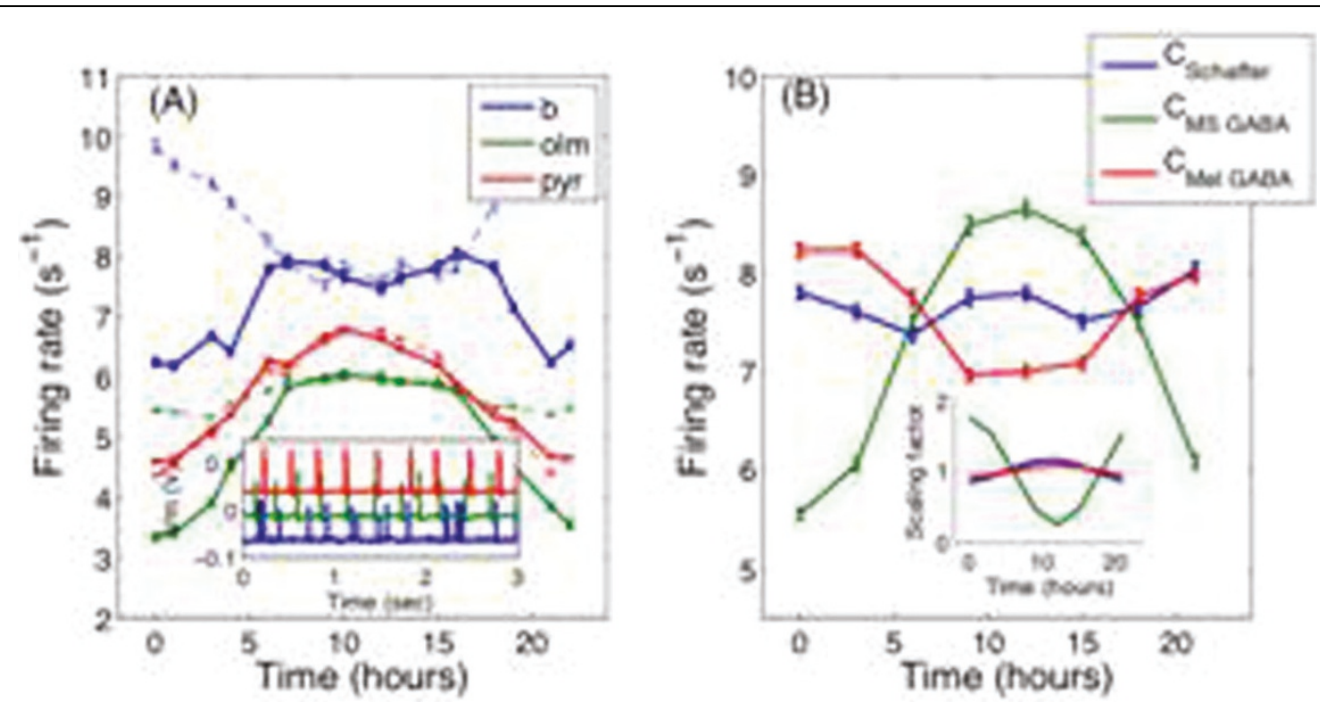

Figure 1 (A) The mean firing rates in the healthy rat (thick) are compared to the injured rat (thin, dotted), showing a $180^{\circ}$ phase shift in basket cell firing. Inset shows sample time series from which firing rates were derived. (B) Basket cell firing rate in response to the three individually applied circadian inputs. Removal of $C_{\text {MS-GABA }}$ input allows $C_{\text {Mel-GABA }}$ signal to take over and produce the $180^{\circ}$ shift. Inset: Modulation of circadian scaling factors $C_{\{i\}}$ used to perturb the system.

\footnotetext{
* Correspondence: talathi@peds.ufl.edu

${ }^{2}$ Division of Pediatric Neurology, Department of Pediatrics, University of

Florida, Gainesville, Florida 32610, USA

Full list of author information is available at the end of the article
}

@ 2011 Stanley et al; licensee BioMed Central Ltd. This is an open access article distributed under the terms of the Creative Commons
Attribution License (http://creativecommons.org/licenses/by/2.0), which permits unrestricted use, distribution, and reproduction in :10 Lea Central Attribution License (http://creativecommons.org/licenses/by/2 
induced by brain injury. We have constructed a biophysically realistic CA1 network model, consisting of pyramidal (Pyr), basket (B), and oriens-lacunosum molecular (O-LM) cells. Based on evidence from the literature, we consider three circadian-like inputs to the network: GABAergic input from the medial septum, peaking at night ( $C_{M S}$ GABA $)$; glutamtergic input along the Schaffer collaterals, peaking during the day $\left(\mathrm{C}_{\mathrm{Schaffer}}\right)$; and melatonin release, peaking at night and acting to attenuate all GABAergic currents $\left(\mathrm{C}_{\mathrm{Mel} \mathrm{GABA}}\right)$. All three circadian inputs are implemented by modulating simulation parameters with a scaling factor $C_{\{i\}}=\left[1+\alpha * \cos \left(2 \pi\left(t-t_{0}\right) /\right.\right.$ 24)].

The main result of our simulation is presented in Figure $1 \mathrm{~A}$. By simulating circadian drive onto the CA1 network of a healthy rat, we show that the firing rates of the three neural populations oscillate in phase (thick lines). For simulation of the circadian perturbations induced by injury, we incorporate our recent high-field brain MRI results. This study, performed in the same animal model, suggested damage to the fimbria-fornix occurred following stimulation. The fimbria-fornix carries the GABAergic septal input. Removing this input from our model produces an $180^{\circ}$ shift in basket cell firing. Thus, our model provides a possible mechanism (Figure 1B) for the experimentally observed PS phase shift in injured animals, and points to input along the fimbria-fornix as an important source for circadian modulation in the hippocampus.

\footnotetext{
Author details

'School of Biological and Health Systems Engineering, Arizona State University, Tempe, Arizona 85287, USA. ²Division of Pediatric Neurology, Department of Pediatrics, University of Florida, Gainesville, Florida 32610 , USA. ${ }^{3}$ Department of Neuroscience, University of Florida, Gainesville, Florida 32610, USA. ${ }^{4} \mathrm{~J}$ Crayton Family Department of Biomedical Engineering, University of Florida, Gainesville, Florida 32610, USA. ${ }^{5}$ McKnight Brain Institute, University of Florida, Gainesville, Florida 32610, USA. ${ }^{6}$ Department of Biochemistry and Molecular Biology, University of Florida, Gainesville, Florida 32610, USA.

Published: 18 July 2011

\section{References}

1. Talathi S, Hwang D, Ditto W, Mareci T, Sepulveda H, Spano M, Carney P: Circadian control of neural excitability in an animal model of temporal lobe epilepsy. Neuroscience letters 2009, 455(2):145-149.

2. Fisher N, Talathi S, Carney P, Ditto W: Effects of phase on homeostatic spike rates. Biological cybernetics 2010, 102(5):427-440.

3. Parekh M, Carney P, Sepulveda H, Norman W, King M, Mareci T: Early MR diffusion and relaxation changes in the parahippocampal gyrus precede the onset of spontaneous seizures in an animal model of chronic limbic epilepsy. Experimental neurology 2010, 224(1):258-270.

doi:10.1186/1471-2202-12-S1-P76

Cite this article as: Stanley et al:: Phase shift in hippocampal circadian rhythm during the latent period of epileptic rats. BMC Neuroscience 2011 12(Suppl 1):P76.
}

\section{Submit your next manuscript to BioMed Central and take full advantage of:}

- Convenient online submission

- Thorough peer review

- No space constraints or color figure charges

- Immediate publication on acceptance

- Inclusion in PubMed, CAS, Scopus and Google Scholar

- Research which is freely available for redistribution

Submit your manuscript at www.biomedcentral.com/submit
C Biomed Central 